\title{
THE TOXICITY AND BIOACTIVITY OF CLIMBING WEDELIA POWDER AND ESSENTIAL OIL AGAINST MAIZE WEEVIL
}

\author{
RUCHUON WANNA*, DARIKAUNPHAN, WARANYOO KAEWDUANGTA, MONGKOL \\ WONGSAWAS AND PHIRAYOT KHAENGKHAN
}

The Faculty of Technology, Mahasarakham University, Mahasarakham 44150, Thailand.

*Corresponding author: ruchuon.w@msu.ac.th

Submitted final draft: 24 August $2020 \quad$ Accepted: 17 October $2020 \quad$ http://doi.org/10.46754/jssm.2021.02.011

\begin{abstract}
Many types of powders and essential oils derived from plants are used as traditional protection for stored products against insect pests. They are relatively non-toxic to mammals and they meet the criteria for reduced risk pesticides. The toxicity and bioactivity of the powder and essential oil of the climbing wedelia, Wedelia trilobata (L.) A.S. Hitchcock, were determined against maize weevil, Sitophilus zeamais Motschulsky. The powder and essential oil were obtained from the aerial parts of $W$. trilobata and tested for their toxicity, as well as insecticidal and residual activities, against $S$. zeamais. The $\mathrm{LC}_{50}$ value of the $W$. trilobata powder to $S$. zeamais was $582.86 \mathrm{~g} / \mathrm{kg}$ grain within 72 hours, while the essential oil was $1,146.19 \mu \mathrm{L} / \mathrm{L}$ air within 24 hours. Mixing powder with grain at a dosage of $80 \mathrm{~g} / \mathrm{kg}$ grain killed $S$. zeamais at $7.50 \%$ after 12 days of exposure and reduced the progeny of $S$. zeamais by $89.96 \%$. After fumigation, concentrations of 150 , 200 and $250 \mu \mathrm{L} / \mathrm{L}$ air of $W$. trilobata essential oil showed $2.50 \%, 5.00 \%$ and $12.50 \%$ of adult mortalities in S. zeamais after 24 hours of exposure, with $81.97 \%$, $83.07 \%$ and $97.65 \%$ reductions in progeny, respectively. The $W$. trilobata powder and essential oil showed efficacy in the protection against the newly emerged progeny of $S$. zeamais $(>80 \%)$. The $W$. trilobata essential oil exhibited moderate to strong residual activities. The results suggest that the powder and essential oil of $W$. trilobata may be effectively used in the management of $S$. zeamais populations in grain storage.
\end{abstract}

Keywords: Plant products, toxicity, insect pests, insecticidal activity, residual activity.

\section{Introduction}

Insect pests cause quantitative and qualitative losses to stored grain products at the farmers' level (Kadjo et al., 2016). Sitophilus zeamais Motschulsky (Coleoptera: Curculionidae) is a serious pest of stored grain in Thailand (Hayashi et al., 2004). The damage caused by $S$. zeamais on stored rice grain is extremely high in tropical and subtropical regions (Ribeiro et al., 2014), decreasing the weight of agricultural products and consequently its market and nutritional values (Temesgen and Waktole, 2013). The management of $S$. zeamais populations is generally controlled with insecticides. Traditional control methods are based on the use of chemical compounds, such as phosphine, methyl bromide, chlorpyrifos-methyl and deltamethrin (Tadesse and Subramanyam, 2018). Nerio et al. (2010) reported that synthetic insecticides adversely affect human health and cause environmental pollution. Research efforts are currently focused on finding alternative nonchemical, ecologically friendly strategies that can be used to reduce or eliminate $S$. zeamais in storage systems. Alternative treatments, such as modified atmospheres, low temperatures, microbial insecticides, plant extracts, and inert dusts, are currently of interest for the control of stored product insect pests, in agreement with the principles of the Integrated Pest Management (Athanassiou et al., 2007; Riudavets et al., 
2014; Campolo et al., 2013) with low toxicity to mammals (Regnault-Roger et al., 2012), rapid degradability and minimal impacts on the germination of plants (Cloyd, 2004).

Natural pesticides made from secondary plant substances can also be used as alternatives for synthetic insecticides. Plants with insecticidal properties are currently one of the most studied alternative methods to control stored product insect pests. This method is widely used throughout the world due to ease of application and the nature of the substrate to be protected. The use of powders is preferred to other plant derivatives (Procópio et al., 2003). A large number of plant substances have physiological and behavioral effects on stored product pests, and are used as alternatives to synthetic insecticides (Rajedran and Sriranjini, 2008). Recent research has turned toward selective biorational pesticides that are safer, cheaper and easier to produce than synthetic insecticides. The application of selected plant products as powders or active isolates, such as essential oils, represents a simple, effective and relatively safe control method that is available to manage the populations of stored product insect pests (Koul et al., 2008; Jindal et al., 2013). Several plant species applied as powders or essential oils showed protective effects against stored grain insects, including toxicity, as well as antifeeding, repellence and growth inhibitory activities (Kéita et al., 2001; Tapondjou et al., 2002; Kim et al., 2010; Nenaah \& Ibrahim, 2011; Kim \& Lee, 2014; Wanna \& Krasaetep, 2019; Wanna \& Kwang-Ngoen, 2019).

\section{Wedelia trilobata (L.) A.S. Hitchcock} is a member of the Asteraceae (formerly Compositae), the sunflower or daisy family. It is a notoriously invasive weed that occurs in a wide range of tropical and subtropical areas (IUCN, 2001). The major chemical constituents of $W$. trilobata are ent-kaurane diterpenes, sesquiterpene lactones and triterpenes. These have a variety of biological activities, such as antibacterial, antitumor, hepatoprotective and central nervous system depressant properties (Wu \& Zhang, 2008; Li et al., 2016). This plant species is well known for its natural properties in Thai traditional medicine, and has been reported to possess several types of biological activities. Numerous anti-insect properties of the plant involve toxic effects against many insects (Yooboon et al.,2019).W. trilobata crude extracts have a larvicidal effect on Spodoptera litura, S. exigua and Plutella xylostella larvae after topical application (Junhirun et al., 2018). The insecticidal activity of the essential oils of many plants might be attributed to monoterpenoids (Tong \& Coats, 2010). Monoterpenoids has been reported as fumigants and contact toxicants for various insect pests (Rice \& Coats, 1994). The major volatile constituents of the $W$. trilobata essential oil obtained from leaves were alphapinene, germacrene $\mathrm{D}, \mathrm{d}$-limonene (Nirmal et $a l, 2005)$ and phellandrene (Khater \& Shafeiy, 2015). Here, the toxicity and bioactivity of the powder and essential oil of the climbing wedelia, $W$. trilobata, were evaluated against the adult stage of $S$. zeamais under laboratory conditions.

\section{Materials and Methods}

\section{Insect Rearing}

Maize weevil, S. zeamais, from grain storages located in Kantharawichai district, Maha Sarakham Province, Thailand, was used throughout this study. Fifteen pairs of adults were maintained in a square plastic box with a width of $15 \mathrm{~cm}$ and height of $30 \mathrm{~cm}$. The cultures were reared on $1 \mathrm{~kg}$ of jasmine rice, Oryza sativa L. at $30 \pm 5{ }^{\circ} \mathrm{C}$ and $70 \pm 5 \%$ relative humidity, with 12:12 h light/dark cycle, and they were allowed to mate and oviposit. The maize weevil adults used for the tests were 7 days old.

\section{Collection and Preparation of $W$. trilobata Powder}

The aerial parts of $W$. trilobata were collected from local gardens at Mahasarakham University, Thailand. Fresh samples were dried in a hot air oven at $30{ }^{\circ} \mathrm{C}$ for 3 days. The dried parts were turned into powder using an electric blender and sieved through mesh size $0.5 \mathrm{~mm}$. The resulting fine powder was maintained in a tightly seated dry bag until required for use in further bioassays. 


\section{Extraction of W. trilobata Essential Oil}

Powdered samples of $W$. trilobata were subjected to hydrodistillation using a modified Clevengertype apparatus to obtain the essential oil. The extraction conditions were $150 \mathrm{~g}$ powders: $1,500 \mathrm{ml}$ distilled water with distillation for 6 hours. The essential oil was removed from the remaining water after extraction by centrifugation at 8,000 rpm for 10 minutes. Oil yield $(\% \mathrm{v} / \mathrm{w})$ was calculated on a dry weight basis. The extracted oil was preserved in a sealed amber glass bottle and refrigerated in the dark at $4{ }^{\circ} \mathrm{C}$ until required for use.

\section{Contact Toxicity of the Dry Ground Powder Admixed with Grains}

This experiment was conducted according to Nenaah and Ibrahim (2011). The fine powder of $W$. trilobata was mixed with $50 \mathrm{~g}$ of jasmine rice grain in $250 \mathrm{~mL}$ glass bottles at concentrations of 20,40, 60 and $80 \mathrm{~g} / \mathrm{kg}$ grain. Powder/grain admixtures were thoroughly hand-mixed with a rotary shaker for 15 minutes to ensure complete mixing homogenization. The $S$. zeamais adults were transferred in groups of five pairs (7 days old) into $250 \mathrm{~mL}$ glass bottles containing treated or untreated (control) grain. The glass bottles were covered with fixed cotton cloths and maintained at the same laboratory conditions described for rearing. Four replicates were performed for each treatment along with the control. The number of deaths of $S$. zeamais adults was counted daily and the mortality percentages were calculated after 3, 6 and 12 days of exposure. Another experiment was conducted to determine the $\mathrm{LC}_{50}$ and $\mathrm{LC}_{95}$ values of the $W$. trilobata powder. Maize weevils were exposed to treated grain in the same manner and mortality counts were recorded 72 hours posttreatment. The mortality data were corrected for control mortality according to Abbott's formula (Abbott, 1925) when mortality in the control ranged between 5\% and 20\%. Probit analysis was used to analyze the dose-mortality response (Finney, 1971) and $\mathrm{LC}_{50}$ and $\mathrm{LC}_{95}$ values were estimated.

\section{Fumigant Toxicity of W. trilobata Essential Oil}

The fumigant toxicity of the essential oil was investigated as previously described by Wanna and Krasaetep (2019). Whatman (no.1) filter paper strips $\left(1.5^{\prime} 5 \mathrm{~cm}\right)$ were impregnated with $100 \mu \mathrm{L}$ of $50,100,150,200$ and 250 $\mu \mathrm{L} / \mathrm{L}$ air dilution of $W$. trilobata essential oil as prepared earlier. After evaporating the solvent for 2 minutes at room temperature, filter paper strips were hung in the glass vials (diameter $2.5 \mathrm{~cm}$ ' height $5 \mathrm{~cm}$ ) from the center of the screw-capped fumigation bottles (diameter 5.5 $\mathrm{cm}$ ' height $10.5 \mathrm{~cm}$ ) to avoid contact with the insects. Each fumigation bottle contained 50 $\mathrm{g}$ of grain. Five pairs of adult maize weevil (7 days) were transferred into each fumigation bottle for the vapor-phase test. The cap of each bottle was screwed tightly shut and the bottles were kept at $30 \pm 5{ }^{\circ} \mathrm{C}$ and $70 \pm 5 \%$ relative humidity and $12: 12 \mathrm{~h}$ light/dark cycle. In the control sets, insects were fumigated with $100 \%$ hexane without any of the tested materials. Adult mortality was observed after 1 and 24 hours of exposure. The insects were considered to be dead if no leg or antennal movements were detected. Each set of treatments was repeated four times and the percentage of adult mortality was calculated using the Abbott formula. Fumigant toxicity was expressed as $\mu \mathrm{L} / \mathrm{L}$ air. Another experiment was conducted to determine the $\mathrm{LC}_{50}$ and $\mathrm{LC}_{95}$ values of the $W$. trilobata essential oil. Maize weevils were exposed to the treated fumigation bioassay and mortality counts were recorded 24 hours after treatment. Mortality data were corrected for control mortality according to Abbott's formula (Abbott, 1925) when mortalities in the control ranged between $5 \%$ and $20 \%$. Probit analysis was used to analyze the dose-mortality response (Finney, 1971), and $\mathrm{LC}_{50}$ and $\mathrm{LC}_{95}$ values were assessed.

\section{Effect on $F_{1}$ Progeny Production of S. zeamais}

In previous experiments, after counting parental mortality, the grain was sieved and the remaining living adults were removed. The bottles were kept under the same experimental conditions 
until the emergence of $F_{1}$ progeny of $S$. zeamais. Based on the life cycle of the untreated control, the counting period of $\mathrm{F}_{1}$ progeny of $S$. zeamais was established so as to avoid an overlap of generations. The percentage reduction in adult emergence or inhibition rate ( $\%$ IR) was calculated by the following equation: $\% \mathrm{IR}=$ (Cn - Tn) ' 100 / Cn (Tapondjou et al., 2002), where $\mathrm{Cn}$ is the number of newly emerged insects in the untreated (control) grain and Tn is the number of newly emerged insects in the grain treatment.

\section{Results}

\section{Contact Toxicity}

The effect of the $W$. trilobata powder on the percentage mortality and progeny production of $S$. zeamais was dependent on exposure time and dose. The $\mathrm{LC}_{50}$ and $\mathrm{LC}_{95}$ values of the $W$. trilobata powder admixed with grain on adults of $S$. zeamais were 582.86 and $1,097.14 \mathrm{~g} / \mathrm{kg}$ grain, respectively (Table 1). The adult mortality of $S$. zeamais on grain admixed with $W$. trilobata powder varied with dosage and exposure time. The $W$. trilobata powder gave low activity to
S. Zeamais, with resistance for all treatments at less than $8 \%$ adult mortality. A dosage of $80 \mathrm{~g} /$ $\mathrm{kg}$ grain killed $S$. zeamais adults at $7.50 \pm 0.96 \%$ after 12 days of exposure, with results not significantly different $(p>0.05)$ for all exposure periods (Table 2).

\section{Fumigant Toxicity}

The effect of the $W$. trilobata essential oil on percentage mortality and progeny production of $S$. zeamais was also dependent on exposure time and concentration. The $\mathrm{LC}_{50}$ and $\mathrm{LC}_{95}$ values of the $W$. trilobata essential oil on adults of $S$. zeamais by vapor phase test were $1,146.19$ and $2,130.88 \mu \mathrm{L} / \mathrm{L}$ air, respectively (Table 3 ). Analysis of variance demonstrated that the $W$. trilobata essential oil on adult mortality rate of $S$. zeamais gave the highest significant difference ( $\mathrm{p} £ 0.01$ ) on the basis of concentration rate after 24 hours of exposure. S. zeamais also showed resistance to $W$. trilobata essential oil, especially at the high dosage rate of $250 \mu \mathrm{L} / \mathrm{L}$ air and 24 hours exposure period, when adult mortality reached $12.50 \pm 1.31 \%$ (Table 4 ).

Table 1: Contact toxicity of Wedelia trilobata powder against adult Sitophilus zeamais at 24 hours

\begin{tabular}{ccccc}
\hline $\mathbf{n}$ & $\begin{array}{c}\text { Linear regression } \\
\mathbf{y}=\mathbf{a x}+\mathbf{b}\end{array}$ & $\begin{array}{c}\mathbf{L C}_{\mathbf{5 0}} \\
(\mathbf{g} / \mathbf{k g} \text { grain })\end{array}$ & $\begin{array}{c}\mathbf{L C}_{\mathbf{9 5}} \\
(\mathbf{g} / \mathbf{k g} \text { grain })\end{array}$ & $\begin{array}{c}\mathbf{r}^{\mathbf{2}} \\
\text { value }\end{array}$ \\
\hline 200 & $\mathrm{y}=0.0875 \mathrm{x}-1$ & 582.86 & $1,097.14$ & 0.82 \\
\hline
\end{tabular}

n presents 200 insects of all adult $S$. zeamais tested. $\mathrm{LC}_{50}$ represents the lethal median concentration.

Table 2: Mortality of Sitophilus zeamais exposed to Wedelia trilobata powder mixed with grains at different concentrations

\begin{tabular}{cccc}
\hline Dose & \multicolumn{3}{c}{ Mortality $(\%$ mean \pm SE) after exposure period } \\
(g/kg grain) & 3 days & $\mathbf{6}$ days & 12 days \\
\hline Control & $0.00 \pm 0.00$ & $0.00 \pm 0.00$ & $0.00 \pm 0.00$ \\
20 & $0.00 \pm 0.00$ & $0.00 \pm 0.00$ & $0.00 \pm 0.00$ \\
40 & $2.50 \pm 0.50$ & $2.50 \pm 0.50$ & $2.50 \pm 0.50$ \\
60 & $2.50 \pm 0.50$ & $2.50 \pm 0.50$ & $2.50 \pm 0.50$ \\
80 & $7.50 \pm 0.96$ & $7.50 \pm 0.96$ & $7.50 \pm 0.96$ \\
F-test & $\mathrm{ns}$ & $\mathrm{ns}$ & $\mathrm{ns}$ \\
\hline
\end{tabular}

ns represents non-significant difference $(\mathrm{p}>0.05)$. 
Table 3: Fumigant toxicity of Wedelia trilobata essential oil against adult Sitophilus zeamais at 24 hours

\begin{tabular}{ccccc}
\hline $\mathbf{n}$ & $\begin{array}{c}\text { Linear regression } \\
\mathbf{y}=\mathbf{a x}+\mathbf{b}\end{array}$ & $\begin{array}{c}\mathbf{L C}_{\mathbf{5 0}} \\
(\boldsymbol{\mu} \mathbf{L} \mathbf{L} \text { air })\end{array}$ & $\begin{array}{c}\mathbf{L C}_{\mathbf{9 5}} \\
(\boldsymbol{\mu} \mathbf{L} / \mathbf{L} \text { air })\end{array}$ & $\begin{array}{c}\mathbf{r}^{2} \\
\text { value }\end{array}$ \\
\hline 200 & $\mathrm{y}=0.0457 \mathrm{x}-2.381$ & $1,146.19$ & $2,130.88$ & 0.76 \\
\hline
\end{tabular}

$\mathrm{n}$ presents 200 insects of all adult $S$. zeamais tested. $\mathrm{LC}_{50}$ represents the lethal median concentration.

Table 4: Mortality of Sitophilus zeamais exposed to Wedelia trilobata essential oil using fumigation bioassay

\begin{tabular}{ccc}
\hline $\begin{array}{c}\text { Concentration } \\
(\boldsymbol{\mu} \mathbf{L} / \mathbf{L} \text { air })\end{array}$ & $\begin{array}{c}\text { Mortality }(\% \text { mean } \pm \text { SE) after exposure period } \\
\mathbf{1} \text { hour }\end{array}$ & $\mathbf{2 4}$ hours \\
\hline Control & $0.00 \pm 0.00$ & $0.00 \pm 0.00 \mathrm{c}$ \\
50 & $0.00 \pm 0.00$ & $0.00 \pm 0.00 \mathrm{c}$ \\
100 & $0.00 \pm 0.00$ & $0.00 \pm 0.00 \mathrm{c}$ \\
150 & $0.00 \pm 0.00$ & $2.50 \pm 0.31 \mathrm{bc}$ \\
200 & $0.00 \pm 0.00$ & $5.00 \pm 0.62 \mathrm{~b}$ \\
250 & $0.00 \pm 0.00$ & $12.50 \pm 1.31 \mathrm{a}$ \\
\hline F-test & N/A & $* *$ \\
\hline
\end{tabular}

N/A represents not applicable. $* *$ represents significant difference at $\mathrm{p} \leq 0.01$.

Means within the same column followed by the same letter are not significantly different (LSD: $\mathrm{p}>0.05$ ).

\section{Effect on $F_{1}$ Progeny Production}

In all cases, significant differences ( $\mathrm{p} £ 0.01$ ) were observed in the numbers of newly emerged $S$. zeamais adults with the treatment of $W$. trilobata powder and essential oil at different doses, concentrations and exposure times. The $\mathrm{F}_{1}$ progeny of $S$. zeamais decreased with the increase of dose rates and concentrations of $W$. trilobata. Fewer numbers of newly emerged $S$. zeamais adults were observed for all $W$. trilobata powders and essential oils when compared with the control (without $W$. trilobata treatment). The W. trilobata powder at the highest dose $(80 \mathrm{~g} /$ $\mathrm{kg}$ grain) gave the lowest number of newly emerged adults $(31.00 \pm 3.24)$ and the highest reduction in adult $\mathrm{F}_{1}$ progeny, reaching $89.96 \%$ (Table 5). The highest concentration $(250 \mu \mathrm{L} / \mathrm{L}$ air) of $W$. trilobata essential oil showed the lowest number of newly emerged $S$. zeamais adults $(3.75 \pm 0.44)$, with $97.65 \%$ reduction in adult $\mathrm{F}_{1}$ progeny (Table 6).

Table 5: $\mathrm{F}_{1}$ progeny of Sitophilus zeamais exposed to Wedelia trilobata powder mixed with grains at different concentrations

\begin{tabular}{ccc}
\hline Dose & \multicolumn{2}{c}{ F $_{\mathbf{1}}$ progeny after exposure period } \\
$\mathbf{( g / k g}$ grain) & New emerged adults $(\mathbf{m e a n} \pm \mathbf{S E})$ & $\mathbf{( \% )}$ Reduction $(\mathbf{I R})$ \\
\hline Control & $308.75 \pm 17.49 \mathrm{a}$ & - \\
20 & $206.25 \pm 12.38 \mathrm{ab}$ & 33.20 \\
40 & $146.75 \pm 9.49 \mathrm{bc}$ & 52.47 \\
60 & $101.75 \pm 7.25 \mathrm{c}$ & 67.04 \\
80 & $31.00 \pm 3.24 \mathrm{~d}$ & 89.96 \\
\hline F-test & $* *$ & - \\
\hline
\end{tabular}

** represents significant difference at $\mathrm{p} \leq 0.01$.

Means within the same column followed by the same letter are not significantly different (LSD: $\mathrm{p}>0.05$ ). 
Table 6: $\mathrm{F}_{1}$ progeny of Sitophilus zeamais exposed to Wedelia trilobata essential oil by fumigation bioassay

\begin{tabular}{|c|c|c|}
\hline \multirow{2}{*}{$\begin{array}{c}\text { Concentration } \\
(\mu \mathrm{L} / \mathrm{L} \text { air })\end{array}$} & \multicolumn{2}{|c|}{$F_{1}$ progeny after exposure period } \\
\hline & New emerged adults (mean \pm SE) & (\%) Reduction (IR) \\
\hline Control & $159.50 \pm 5.73 \mathrm{a}$ & - \\
\hline 50 & $62.50 \pm 2.71 \mathrm{~b}$ & 60.82 \\
\hline 100 & $58.50 \pm 2.59 \mathrm{~b}$ & 63.32 \\
\hline 150 & $28.75 \pm 1.89 \mathrm{c}$ & 81.97 \\
\hline 200 & $27.00 \pm 1.87 \mathrm{c}$ & 83.07 \\
\hline 250 & $3.75 \pm 0.44 \mathrm{~d}$ & 97.65 \\
\hline F-test & $* *$ & - \\
\hline
\end{tabular}

\section{Discussion}

One of the most valued properties of natural plant products is their toxic activity against insects. They can be successfully used to control pests in storage systems to minimize or even replace the application of harmful chemical pesticides. W. trilobata applied as powder or essential oil showed residual effect of contact and fumigant activities against $S$. zeamais. The toxicity of the powder and essential oil varied with the dosage of the plant products and time of exposure. In Thailand, plant powders have been mixed with stored grain since ancient times. This method can be used as a natural, safe, and less expensive strategy to protect grain from insect infestations. Most previous experiments focused on testing the activity of plant products over short periods of time. However, for practical utilization of plant materials to protect stored grain products, further information is required on the residual effects of these biorationals over longer time durations against key insect species (Ilboudo et $a l ., 2010)$. The efficiency of botanicals also needs to be assessed in more realistic conditions to determine their activity at the farm level, as well as at the storage level. Unlike other botanicals, such as essential oils and volatile components that undergo thermal and/or photodegradation, plant powders retain some of their properties over time and, hence, could be used as grain protectants when admixed in stores. Our results revealed significant oviposition deterrence and strong inhibition of $S$. zeamais adult emergence
(F1 offspring) in jasmine rice grain treated with $W$. trilobata powder at $40-80 \mathrm{~g} / \mathrm{kg}$ grain and $50-250 \mu \mathrm{L} / \mathrm{L}$ air for $W$. trilobata essential oil. Major constituents of crude oil delayed the metamorphosis of larvae with the production of sterile, moribund and dwarfish adults (Fagoonee and Umrit, 1981). Nowadays, more research has been done to discover alternative effective methods to manage pests without environmental contamination from the use of conventional pesticides. Essential oils are regarded as a new class of ecological natural products for controlling insect pests. The development of safe and scientifically proven herbal products should be given priority in an increasingly regulated world. Concerns for essential oil residues on food crops are alleviated by growing evidence that many essential oil constituents acquired through diets are beneficial for human health (Huang et al., 1994).

\section{Conclusion}

The $W$. trilobata essential oil exhibited moderate to strong residual activity against $S$. zeamais. The $W$. trilobata powder and essential oil showed efficacy in the protection against newly emerged progeny $(>80 \%)$ of $S$. zeamais. Our results suggest that $W$. trilobata can be used effectively for the management of $S$. zeamais in grain storage when applied as powder or essential oil. The use of botanicals should be encouraged in small farm storage 
due to their low cost and abundant availability to ameliorate losses incurred in untreated seed. The application of plant products on grain seed during storage is an inexpensive and effective technique, and a technology that can be readily accepted by farmers. Assessments of appropriate formulations for utilization in grain storage should be extended to evaluate mammalian safety and insecticidal mode of action.

\section{Acknowledgements}

The authors thank the Department of Agricultural Technology, Faculty of Technology, Mahasarakham University, for providing the instruments. Laboratory assistance from Mr. Suphanat Wongkangchurit is gratefully acknowledged.

\section{References}

Abbott, W. S. (1925). A method for computing the effectiveness of an insecticide. Journal of Economic Entomology, 18, 265-267.

Athanassiou, C. G., Kavallieratos, N. G., \& Meletsis, C. M. (2007). Insecticidal effect of three diatomaceous earth formulations, applied alone or in combination, against three stored-product beetle species on wheat and maize. Journal of Stored Product Research, 43, 330-334.

Campolo, O., Verdone, M., Laudani, F., Malacrinò, A., Chiera, E., \& Palmeri, V. (2013). Response of four stored products insects to a structural heat treatment in a flourmill. Journal of Stored Product Research, 54, 54-58.

Cloyd, R. A. (2004). Natural indeed: are natural insecticides safer and better than conventional insecticides? Ill. Pesticide Review, 17(3), 1-7.

Fagoonee, I., \& Umrit, G. (1981). Antigonadotropic hormones from the goat weed, Ageratum conyzoides. Insect Science and Its Application, 4, 373-376.

Finney, D. J. (1971). Probit Analysis, 3rd ed. Cambridge University Press, London.
Hayashi, T., Nakamura, S., Visarathanonth, P., Uraichuen, J., \& Kengkanpanich, R. (2004). Stored rice insect pest and their natural enemies in Thailand. Japan. International Research Centre for Agricultural Sciences, Bangkok. International, Agricultural Series No.13.

Huang, M., Ferraro, T., \& Ho, C. (1994). Cancer chemoprevention by phytochemicals in fruits and vegetables. American Chemical Social Symposium Series, 546, 2-16.

Ilboudo, Z., Dabiré, L. C., Nébié, R., Dicko, I., Dugravot, S., Cortesero, A., \& Sanon, A. (2010). Biological activity and persistence of four essential oils towards the main pest of stored cowpeas, Callosobruchus maculatus (F.) (Coleoptera: Bruchidae). Journal of Stored Product Research, 46, 124-128.

IUCN. (2001). 100 of the World's Worst Invasive Alien Species; Invasive Species Specialist Group: Auckland, New Zealand.

Jindal, V., Dhaliwal, G. S., \& Koul, O. (2013). Pest management in 21st century: roadmap for future. Biopesticides International, 9(1), $1-22$.

Junhirun, P., Pluempanupat, W., Yooboon, T., Ruttanaphan, T., Koul, O., \& Bullangpoti, V. (2018). The study of isolated alkane compounds and crude extracts from Sphagneticola trilobata (Asterales: Asteraceae) as a candidate botanical insecticide for lepidopteran larvae. Journal of Economic Entomology, 111, 1-7.

Kadjo, D., Ricker-Gilbert, J., \& Alexander, C. (2016). Estimating price discounts for low quality maize in sub-Saharan Africa: evidence from Benin. World Development, 77, 115-128.

Kéita, S. M., Vincent, C., Schmidt, J., Arnason, J. T., \& Bélanger, A. (2001). Efficacy of essential oil of Ocimum basilicum L. and $O$. graticimum L. applied as an insecticidal fumigant and powder to control Callosobruchus maculatus (Fab.) 
(Coleoptera: Bruchidae). Journal of Stored Product Research, 37, 339-349.

Khater, K. S., \& El-Shafeiy, S. N. (2015). Insecticidal effect of essential oils from two aromatic plants against Tribolium castaneum (Herbst), (Coleoptera: Tenebrionidae). Egypt Journal of Biological Pest Control, 25(1), 129-134.

Kim, S. I., \& Lee, D. W. (2014). Toxicity of basil and orange essential oils and their components against two coleopteran stored products insect pests. Journal of AsiaPacific Entomology, 17, 13-17.

Kim, S. I., Yoon, J. S., Jung, J. W., Hong, K. B., Ahn, Y. J., \& Kwon, H. W. (2010). Toxicity and repellency of origanum essential oil and its components against Tribolium castaneum (Coleoptera: Tenebrionidae) adults. Journal of Asia-Pacific Entomology, 13, 369-373.

Koul, O., Walia, S., \& Dhaliwal, G. (2008). Essential oils as green pesticides: potential and constraints. Biopesticides International, 4(1), 63-84.

Li, S. F., Ding, J. Y., Li, Y. T., Hao, X. J., \& Li, S. L. (2016). Antimicrobial diterpenoids of Wedelia trilobata (L.) Hitchc. Molecules, 21, 1-10.

Nenaah, G., \& Ibrahim, S. (2011). Chemical composition and the insecticidal activity of certain plants applied as powders and essential oils against two stored-products coleopteran beetles. Journal of Pest Science, 84, 393-402.

Nerio, L. S., Oliveiro-Verbel, J., \& Stashenko, E. E. (2010). Repellent activity of essential oils: A review. Bioresour Technol, 101, 372378.

Nirmal, S. A., Chavan, M. J., Tambe, V. D., Jadhav, R. S., Ghogare, P. B., Bhalke, R. D., \& Girme, A. S. (2005). Chemical composition and antimicrobial activity of essential oil of Wedelia trilobata leaves. Indian Journal of Natural Product, 21(3), 33-35.
Procópio, S. O., Vendramim, J. D., Ribeiro Junior, J. I., \& Santos, J. B. (2003). Bioatividade de diversos pós de origem vegetal em relação à Sitophilus zeamais Mots. (Coleoptera: Curculionidae). Revista Ciência Agrotécnica, 27(6), 1231-1236.

Rajendran, S., \& Sriranjini, V. (2008). Plant products as fumigants for stored product insect control. Journal of Stored Product Research, 44, 126-135.

Regnault-Roger, C., Vincent, C., \& Arnason, J. T. (2012). Essential oils in insect control: Low-risk products in a high-stakes world. Annual Review Entomology, 57, 405-424.

Ribeiro, L. P., Vendramim, J. D., Andrade, M. S., Bicalho, K. U., Silva, M. F. G. F., Vieria, P. C., \& Fernandes, J. B. (2014). Tropical plant extracts as sources of grain-protectant compounds against Sitophilus zeamais Motchulsky (Coleoptera: Curculionidae). Neotropical Entomology, 43, 470-482.

Rice, P. J., \& Coats, J. R. (2014). Insecticidal properties of several monoterpenoids to the house fly (Diptera: Muscidae), red flour beetle (Coleoptera: Tenebrionidae), and southern maize rootworm (Coleoptera: Chrysomelidae). Journal of Economic Entomology, 87, 1172-1179.

Riudavets, J., Pons, M. J., Gabarra, R., Castañé, C., Alomar, O., Vega, L. F., \& Guri, S. (2014). The toxicity effects of atmospheres with high content of carbon dioxide with addition of sulphur dioxide on two storedproduct pest species: Sitophilus oryzae and Tribolium confusum. Journal of Stored Product Research, 57, 58-62.

Tadesse, T. M., \& Subramanyam, B. (2018). Efficacy of filter cake and Triplex powders from Ethiopia applied to wheat against Sitophilus zeamais and Sitophilus oryzae. Journal of Stored Product Research, 79, 40-52.

Tapondjou, L. A., Adler, C., Bouda, H., \& Fontem, D. A. (2002). Efficacy of powder and essential oil from Chenopodium ambrosioides leaves as postharvest grain 
protectants against six-stored product beetles. Journal of Stored Product Research, 395-402.

Temesgen, K., \& Waktole, S. (2013). Differential resistance of maize varieties to maize weevil (Sitophilus zeamais Motschulsky) (Coleoptera: Curculionidae) under Laboratory Conditions. Journal of Entomology, 10, 1-12.

Tong, F., \& Coats, J. R. (2010). Effects of monoterpenoid insecticides on [3H]-T BOB binding in house fly GABAA receptor and 36 uptake in American cockroach ventral nerve cord. Pesticide Biochemistry and Physiology, 98(3), 317-324.

Wanna, R., \& Krasaetep, J. (2019). Chemical composition and insecticidal activity of essential oil from Indian borage against maize weevil. International Journal of GEOMATE, 16(56), 59-64.

Wanna, R., \& Kwang-Ngoen, P. (2019). Efficiency of Indian borage essential oil against cowpea bruchids. International Journal of GEOMATE, 16(56), 129-134.

Wu, M. L., \& Zhang, D. Z. (2008). Progress of researches on the invasive plant Wedelia trilabata. Pharmacy Today, 6, 21-23.

Yooboon, T., Pengsook, A., Ratwatthananon, A., Pluempanupat, W., \& Bullangpoti, V. (2019). A plant-based extract mixture for controlling Spodoptera litura (Lepidoptera: Noctuidae). Chemical and Biological Technologies in Agricultural, 6(5), 1-10. 